\title{
PRIORITISING HIGHER EDUCATION: WHY RESEARCH IS ALL THAT MATTERS
}

\author{
N. Davids* \\ e-maill: nur@sun.ac.za
}

\section{Y. Waghid*}

yw@sun.ac.za

*Department of Education Policy Studies

Stellenbosch University

Stellenbosch, South Africa

\section{ABSTRACT}

Birthdays are joyfully relative events, which, at times, become more about reflection, and at times, regret, with each passing year. As Stellenbosch University embarks on its $100^{\text {th }}$ year, celebrations and commemorations have adopted tentative nuances and burdens of heavily-laden legacies of wrongs and ills, which stand to be corrected. Much has been said, and rightly so, of assuming responsibility for questionable roles in highly divisive and harmful practices. In turn, much is envisaged for future actions of remedy and redress - particularly in relation to social responsibility and community interaction. In considering the role and responsibility of a university, many would agree that if the core of higher education is its epistemological contribution, then its impact is determined by its social worth. In this sense, any teaching and learning should not only be cognisant of its social context, but teaching and learning should always be both responsible and responsive to the world which it encounters. Yet, a university's responsibilities can, and should never be at the expense, or risk of research. As will be discussed in this article, prioritising higher education means prefacing, and giving precedence to research. Prioritising higher education through research creates the spaces necessary for a philosophy of dialogue. Moreover, research is indispensable to meaningful teaching and learning. Put differently, it is with research that a university sustains and advances its intellectual, social and ethical project into the realm of the public. And, this implies a renewed look at the university with an ecological parlance of inquiry that accounts for the university on the basis of assemblages, engagements, reflections and sightings - whether smooth and or striated.

Keywords: higher education, research, teaching and learning, ecological university

\section{RESEARCH AS A PHILOSOPHY OF DIALOGUE}

In his ground-breaking text, I and thou, Martin Buber (1958) argues that human existence is 
fundamentally grounded in relationships - that is, in how we engage with, and relate to the other. The text is described as an example of dialogical existentialism, or a philosophy of dialogue, since much of it is focused on how human beings present themselves, and engage with the other. To Buber (1958) a human being, and hence, human existence is entirely relational - the "I" cannot exist in the absence of the other. Buber maintains that it is not possible to understand the experience of another from a detached or analytical experience (Fife 2015). Rather, understanding another's experience can only be achieved through dialogue, since it is through dialogue that one sees and acknowledges the whole person, and not as a collection of attributes (Fife 2015).

Buber (1958) explains that while the world belongs to the primary word "I-It", the primary word "I-Thou” establishes the world of relation. His contention is that a human being is fundamentally relational - "To be is to be in relation with others". (Fife 2015, 212). Buber maintains that we offer our presence and interaction in relation to three main areas: nature, each other and our spiritual life:

"The spheres in which the world of relation arises are three.

First, our life with nature. There the relation sways in gloom, beneath the level of speech. Creatures live and move over against us, but cannot come to us, and when we address them as Thou, our words ding to the threshold of speech.

Second, our life with [wo]men. There the relation is open and in the form of speech. We can give and accept the Thou.

Third, our life with spiritual beings. There the relation is clouded, yet it discloses itself; it does not use speech, yet begets it.” (Buber 1958, 2).

The concern with the construction of "I-it", is that it symbolises an objectified manner of addressing, and engaging with the other. When we use "I-it", following Buber (1958), we are using only a part of our being; we see the other only as an object, from whom we need to gain something. We are neither interested in presenting our full being to him/her, nor in seeing him/her as a whole person, or acknowledging his/her deep humanity. By contrast, the "I-thou" relation implies an encounter in which individuals are completely present to the other. Following Buber (1958), they address each other with mutuality and in reciprocity; recognizing each other's full humanity - "The primary word I-Thou can only be spoken with the whole being. The primary word I - It can never be spoken with the whole being” $(1958,3)$. When the "I" sees and engages with the "Thou", there is a deep respect through which the other is experienced, and understood.

Research, in a very similar fashion, is about the establishment and cultivation of that which 
is yet to be known. Before embarking upon any piece of research, the researcher has some (limited) idea of what is to be explored or pursued; he/she knows certain parts of what he/she desires to know more about. Research is underscored by a specific curiosity and interest in a particular matter, event, or being. It is the desire to know that, which motivates both the researcher and the research(ed). And the more the researcher reads, analyses, interprets and delves, the more appealing and rich the research(ed) become. It is in this way that the researcher enters into a philosophy of dialogue with the research, and all it encompasses, whether in the form of scientific data, a phenomenon, or a human being. The research becomes the experience itself through which the whole is understood. Through the research which is being researched, is given a voice; it is awakened out of its silence and made known through its own voice. While research often departs from preconceived assumptions and hypotheses, research often serves to bring those assumptions into question, yielding unimagined knowledge.

Buber (1958, 5), continues, that it is said, “that man experiences his world”, but Buber questions what that means. He argues that when a man [or woman] "travels over the surface of things and experiences them", he "extracts knowledge about their constitution from them: he wins an experience from them. He experiences what belongs to the things. But the world is not presented to man by experiences alone. These present him only with a world composed of It and $\mathrm{He}$ and She and It again” (Buber 1958, 5). Following Buber, mere experience of the world and others are not enough to known them in their entirety. But when he enters into a relationship of "I-thou", he meets that world in totality. A researcher, who is embedded in his research lives (temporarily) in that research; he/she questions, reflects, and examines his/her own beliefs in relation to the research. According to Alvesson and Sköldberg (2000), the researcher develops his/her reflexivity, and actively shapes the relationship with his/her research.

Understanding research as a philosophy of dialogue invites and cultivates particular implications of higher education. Too often, both academics and students conceive of higher education only as a production of knowledge - implying a clear gap between the researcher and knowledge, that is, an "I-it" relationship. It becomes about the gathering of data, the accumulation of concepts, or proving this or that hypothesis. When research is understood and approached as an "I-thou”, a relationship unfolds, and this relationship is founded on respect, and embracing the full humanity of what is being encountered. In turn, the academic comes to exist in a professional relationality to his/her research. Higher education cannot be in any other kind of relationship with research, but through an "I-thou" - since this relationship embodies the very purpose of higher education. Research is both the origin and manifestation of the humanity of higher education. Research allows higher education to meet the world and its humanity in totality. 


\section{RESEARCH AS INDISPENSABLE TO TEACHING AND LEARNING}

Learning is driven by a need; it is motivated by the desire to know about this or that. Unless teaching recognises that need, or rather, unless teaching meets the desires of learning, learning will not take place. In this regard, teaching is in need of learning, but learning is not dependent on teaching. Hence, if there were no need for learning, there would be no need for teaching. Firstly, like research, teaching is an entirely relational practice, and is always influenced and shaped by who the teacher is, who the students are, as well as the context of that teaching. These highly complex factors provide us with some idea as to why both teaching and learning are unpredictable, and why ideas of pre-determined learning outcomes are problematic. Indeed, the more teachers attempt to control the dialogue, engagement, and outcomes of learning, the less learning will actually occur. Instead, students are quick to pick up on the direction and focus of their teachers, and if what the teacher is intent on (re)producing rote learning and memorisation, then that is what will be found. But, of course, this should not be confused with actual learning, which is inextricably linked to autonomous thought.

The question and challenge for teachers and teaching is how to stimulate a student's desire to learn? Often, it is the teacher, who stifles a student's interest and willingness to learn, through closed, repressive and uninviting teaching. At the heart of meaningful teaching, is the teacher. It is the teacher who enlivens, or smothers a subject - regardless of the content. Sockett (2012, 5) refers to the unfolding processes of teaching and learning as an "epistemic process". This “epistemic process”, states Sockett $(2012,5)$, is lost when students are discouraged to think, when they are discouraged to be open to different ways of thinking about this or that, or to consider who they might be, as opposed to who they are. Stated differently, this challenge for teachers is to (re)assert their "epistemic presence", so that students might not only encounter knowledge, but develop their own judgement in relation to knowledge. It is up to teachers to create the spaces - no matter how uncomfortable these spaces might be and become - in which students might interrogate who they are, what they believe, why they believe what they do, and recognise the existence of multiple realities, which means that their perspective is just one way of thinking. This point cannot be emphasised enough, not only in relation to South African universities, but globally, as levels of tolerance become increasingly eroded.

So, how can teachers motivate their students to learn, so that higher education fulfils its promise of cultivating educated beings? There are numerous responses that might be considered in this regard. Our focus is on the non-negotiable role and purpose of research in relation to teaching and learning. MacIntyre (1999), for example, asserts that argument - as might be 
encountered in teaching in learning - implies becoming reflective about one's reasons, that is, not only having reasons as wilful action implies, but also to reflect on our reasons within particular social contexts. Reflective action, states MacIntyre (1999, 8), places great emphasis on individual autonomy or the capacity of humans to make independent rational judgements. In this sense, teachers have to understand why they are teaching a particular set of content knowledge, inasmuch as they need to have clarity about how they will teach. Sockett $(2012,4)$ contends that what lies at the heart of teaching, is not content and method, but the problems of knowledge - and specifically how knowledge and virtue are profoundly linked in each part of the teaching domain. Teaching, therefore, cannot be a mundane and prescriptive practice. If teaching is to tap into the desires and life-worlds of students, and hence learning, then it has to be informed by human creativity (Hansen 2008), so that things might be (re)imagined otherwise. And, one can only have a sense and experience of how things be otherwise, if and when one embarks on particular pathways of inquiry, as made manifest through research. To this end, teaching and learning necessarily originate, and lead to research.

A teacher cannot teach with the assurance of learning, if he/she has not learnt about a particular matter herself. Teaching has to be preceded by a curiosity to know, and a willingness to reflect upon what is already known. Furthermore, if teaching is understood as a relational practice to learning, which takes into account student identities, voices and circumstances, then teaching necessarily leads to the opening and asking of more questions. Teaching, states Griffiths $(2013,221)$ is not only “embodied, played out in specific social-cultural contexts”, but it is "changing over the course of a career for reasons beyond the control of any teacher". Teaching, therefore, like learning, are highly fluid practices, continually shifting in response to the world in which it unfolds. What is worthwhile in one year, might be insignificant in the following. When students participate and engage in their own learning, they inevitably come with renewed ways of thinking, of yet to be considered perspectives - establishing the need for more inquiry. What this shows is that research cannot be conceived as separate from teaching and learning. Instead, teaching-learning-research exist on a mutually responsive continuum. These three practices are inter-connected, and have to be understood as such, if higher education is to fulfil its multiple epistemological and social responsibilities.

Thus far, we have looked at research as a philosophy of dialogue. We have also considered the necessity and importance of research in relation to teaching and learning. In the closing section of this article, we turn our attention to how research assists the university in sustaining its intellectual, social and ethical project into the realm of the public. 


\section{RESEARCH AS AN ADVANCEMENT OF THE SOCIAL AND ETHICAL REALM}

It is research that gives the university its impetus for inquiries about teaching, learning, curricula, disciplines, students, and other connections with society. In the case of Stellenbosch University, its centenary year has brought along renewed reflections on its fractured connections with surrounding communities, and those sectors of society, who continue to struggle to find a sense of inclusion and belonging within its structures and ethos.

In a broader context, the distinctiveness of the university, for more than two hundred years, has been its emphasis on inquiry, or what Ron Barnett $(2018,6)$ refers to as "an openness of mind and an open society”. It is such an openness of mind and openness to society that help us to think with optimism about a new kind of university - to which Barnett (2018) refers to as an "ecological" one - that is, one that is both concerned with a real urgency towards the total world, and its ethical responsibility. And here, we are immediately reminded of Buber's (1958) "I-Thou” relationship - which implies a recognition of the whole, rather than its parts. In this sense, openness of mind means being open to the other, as well as being open to think about things in a renewed fashion - as Stellenbosch University is having to do. It is not sufficient to simply stop committing a wrong, as in supporting or advocating indefensible policies and structures. Being open to openness and transparency, and renewed ways of being, means taking stock of the impact of the wrong - that means seeing and recognizing the wrong in its totality, which cannot happen without engaging with the "Thou” of those, who have been wronged and harmed.

Firstly, to speak of the ecological university, Barnett $(2018,27)$ asserts that the university has spaces of agency - that is, "paths of possibilities or even paths of imagination”. The latter implies, more specifically, that the ecological university remains on the look-out for large deficiencies in its own research and in the wider world. The Stellenbosch example, for instance, suggests very specific paths of remedy and retribution. In other words, following Barnett (2018, 53), such a university would continue to develop conversations between its disciplines, stretching its students into strange places, opening dialogues with the wider society, listening attentively to the world and attending to demonstrable issues, and imagining new possibilities for itself and for the world. In sum, the paths of possibilities necessarily have to encompass paths not previously embarked upon, and paths not previously crossed. And of course, attempts continue to be made in relation to expanding student demographics. Mere access of previously excluded students, however, should not be confused with ecological transformation. Human ecologies can only be transformed when they are encountered in their totality, and their presence is recognised in its completion. 
Secondly, the ecological university has an ethical concern to promote democratic interests in helping people understand one another, co-exist, and making sense of the world in which they live. Again, Barnett $(2018,98)$ explains this ethical responsibility as follows: "It [the ecological university] looks out into the world and works with the understandings of the world, so as to develop those understandings. It has about it an epistemological otherness. It operates with a new sense of profit, that of a democratic epistemological surplus, in which public understandings multiply and take on energies of their own ...”. The ethical responsibility of Stellenbosch University and higher education, can only manifest, when research, teaching and learning are conceived as ethical endeavours. What this means is that the very existence and responsibility of higher education ought to be geared towards the cultivation of a public good, and hence, human flourishing. If this is not the case, the ethical realm ceases to be, and any teaching, learning and research stand in contradistinction to the parameters of an ecological university.

In light of the afore-mentioned, the contemporary university cannot be in ruins as there are always unending spaces for new understandings and possibilities along paths of smoothness and striation through which renewed engagements among students and academics potentially lead to new understandings of reason, truth, openness, freedom and communication. In turn, it remains the responsibility and potentiality of Stellenbosch University and other universities in South Africa to reimagine its purpose and role, so that it uses its past as a profound teaching and learning moment of what could be otherwise.

\section{REFERENCES}

Alvesson, M. and K. Sköldberg. 2000. Reflexive methodology: New vistas for qualitative research. London: Sage.

Barnett, R. 2018. The ecological university: A feasible utopia. London \& New York.

Buber, M. 1958. I and thou. Translated by R. Gregor Smith. Edinburgh, T.\&T. Clarke.

Fife, S. T. 2015. Martin Buber's philosophy of dialogue and implications for qualitative family research, Journal of Family Theory and Review 7(3): 208-224.

Griffiths, Morwenna. 2013. "Critically adaptive pedagogical relations: The relevance for educational policy and practice.” Educational Theory 63(3): 221-236.

Hansen, D. T. 2008. "Values and purpose in teacher education.” In Handbook of research on teacher education: Enduring questions in changing contexts ed. Marilyn Cochran-Smith, Sharon FeimanNemsar, D. John McIntyre and Kelly E. Demers, 10-26. $3^{\text {rd }}$ Edition. New York: Routledge.

MacIntyre, A. 1999. Dependent rational animals: Why human beings need the virtues. London: Duckworth.

Sockett, Hugh. 2012. Knowledge and virtue in teaching and learning: The primacy of dispositions. London: Routledge. 